\title{
NAUJOJO MOKSLO - SUDE்TINGŲJŲ DINAMINIŲ SISTEMŲ - TYRIMO PARADIGMA: NUO BIOLOGIJOS IKI TEISĖS
}

\author{
Albertas Skurvydas ${ }^{1,2}$, Dovilè Valančiené $\dot{3}^{3}$ \\ Lietuvos kūno kultūros akademija ${ }^{1}$, Kaunas, Klaipédos universitetas ${ }^{2}$, Klaipèda, \\ Vilniaus universitetas ${ }^{3}$, Vilnius, Lietuva
}

\begin{abstract}
Albertas Skurvydas. Profesorius habilituotas biomedicinos mokslų daktaras. Lietuvos kūno kultūros akademijos rektorius. Mokslinių tyrimu kryptis - motorinès sistemos kompleksinè ir dinaminė adaptacija.

\section{SANTRAUKA}

Straipsnio tikslas — apžvelgti naujojo mokslo — sudetinguju dinaminiu sistemu — tyrimo paradigmos privalumus ir trūkumus biologijos ir socialiniu mokslu srityje (akcentuojant teise). Šiu dienu pasaulyje vyksta mokslo paradigmos kaita. Vyksta pasaulěžiūru sankirtis. Dabar naujasis mokslas verčia senajų moksla. Viena iš didžiausiu senojo mokslo klaidu yra ta, kad išskyrè griežtas ribas tarp mokslu. Todèl atsirado labai daug atskiru mokslo , specialistu“ ir mažai besuprantančiu, kas yra mokslas iš tikruju. Kovoja, nors tai dažnai sunkiai ǰžvelgiama, senasis deterministinis ir mechanistinis mastymas, pagristas visiško aiškumo ir objektyvumo siekiu, su naujuoju — sudètinguju (kompleksiniu) dinaminiu sistemu paradigma, kuri nesuabsoliutina pažinimo galimybiu ir vis labiau supranta, kad kiekvienas pažinimas priklauso ne tik nuo subjekto silpnybiu, bet ir nuo objekto sudètingumo, kaitos, t. y. negalimumo iš principo ji tiksliai pažinti, ištirti, suprasti. Kas laimi šiuo metu? Néra abejonès, kad senasis, labiau patyręs ir daugiau , užtarèju“ “ turintis mokslas. Tačiau pergalè yra gana trapi, nes ¿̇vairiu mokslu lyderiai vis drqsiau kelia senojo mokslo trūkumus ir rodo naujojo privalumus.
\end{abstract}

Raktažodžiai: sudètingosios dinaminès sistemos, chaosas, mokslo paradigma.

\section{IVADAS}

$\breve{\mathrm{S}}$ iuo metu vyksta mokslo paradigmos kaita: klasikinè senojo mokslo paradigma užleidžia erdvę (nors labai sunkiai) naujojo mokslo - sudètinguju (kompleksinių) dinaminiu sistemu (SDS) - paradigmai. Mokslo bendruomenès naujają mokslo paradigmą įvardija ịvairiai postmoderniojo mokslo, evoliucine, naujojo mokslo, konstruktyviaja, sudètingujų dinaminių sistemų, chaoso, kompleksiškumo, netiesinio mąstymo, mokslo humanizavimo paradigma (Skurvydas, 2008). Naujojo mokslo paradigma ištaiso senosios paradigmos klaidas - absoliutaus objektyvumo, aiškumo, apibrěžtumo, deterministinio priežastingumo, prognozuojamumo, redukcionizmo, mokslo dehumanizavimo. Naujojo mokslo paradigma atsirado su kompleksiškumo, netiesiškumo, kintamumo, neapibrèžtumo, neịrodomumo, kuklumo vertinant savo žinojimą, mokslo humanizavimo, 
chaoso, spontaniškumo pasirodymu moksle ir praktikoje. Naujoji paradigma iš esmès keičia požiūrị i mokslo misija, pažinimo šaltinius, mokslini metodą, mokslų (biologijos, fizikos, socialinių, humanitariniu ir kt.) filosofiją, pagaliau mokslo politiką ir vadybą (Skurvydas, 2008).

SDS yra: a) sudaryta iš daugiau nei dviejų elementu, kurie susiję kintamais ryšiais, b) sunkiai suprantama, valdoma ir nuspėjama sistema. Joms priklauso, pavyzdžiui, pasaulis (Forrester, 1971), socialinès sistemos (Elster, 2007), teisè (Von Hayek, 1998; Posner, 2004; Dworkin, 2005; Patterson, 2008), biologinès sistemos (Goodwin, 2003; Skurvydas, 2005; Noble, 2006), gamtos sistemos (Gleick, 1987; Gell-Mann, 1994; Marshall, Zohar, 1997), mokslas (Collins, Pinch, 1993; Skurvydas, 2008). Nobelio premijos laureato I. Prigogine (1997) nuomone, dabar mokslas pasiekè tokią stadija, kai mažiau yra aišku nei neaišku. Anot jo, mokslas privalo „žiūrèti realybei i akis“, visiškai nebijodamas realybės sudètingumo. Taigi mokslas negali apsiriboti tirti tik jam patogius, dažniausiai tvarkingus (jie dažniau pasitaiko laboratorijose nei realiame gyvenime) ir nuspejjamus fenomenus. Pirmiausia jis privalo paaiškinti tokius fenomenus, kurių elgsenos negalima tiksliai nuspetti ir valdyti. Nepaisant SDS mokslo pasiekimų, senojo (klasikinio) mokslo paradigma yra vyraujanti. Ir taip atsitinka dèl to, kad vis dar trūksta aiškesnio SDS paradigmos supratimo. Todèl šio straipsnio tikslas ir yra apžvelgti naujojo mokslo - sudètinguju dinaminiu sistemu — paradigmos privalumus ir trūkumus. Tikiuosi, kad jis ne tik padès aiškiau suprasti, kaip veikia sudètingujų dinaminių sistemu mokslas, bet ir leis įvairių mokslų sričių mokslininkus (biologijos ir socialinių mokslų) remtis naujają paradigma keliant, tikrinat ir aiškinant originalias hipotezes.

\section{NAUJASIS MOKSLAS: KAS TAI?}

Naujasis mokslas - tai tapsmo, bet ne būties mokslas (Prigogine, 1997). Naujojo mokslo paradigma supranta, kad SDS elgsenai būdingas kintamumas, spontaniškumas, chaotiškumas, neprognozuojamumas, netiesiškumas (Gell-Mann, 1994; Bak, 1996; Laszlo, 2002; Skurvydas, 2003). SDS tvarka - tai chaoso tvarka, nes šiandien chaosas suprantamas ne kaip netvarka, bet kaip sunkiai suprantama ir valdoma tvarka (Prigogine, 1997; Kauffman, 2000; Burggren, Monticino, 2005). Galima sakyti, kad pagal SDS dèsnius randasi originali, nepakartojama, iš anksto nežinoma ir trapi tvarka.
Todèl naujojo mokslo paradigma teigia, kad su naujos tvarkos pažinimu baigiasi klasikinis mokslas ir prasideda naujasis, tikrovès nebijantis mokslas.

Naujojo mokslo metaforos - kompleksiškumas, kintamumas, neapibrèžiamumas, katastrofos, chaosas, netiesiškumas, kuklumas vertinant savo žinojimą (Gell-Mann, 1994; Prigogine, 1997; Goodwin, 2001; Laszlo, 2002; Laughlin, 2005; Skurvydas, 2008). Todèl galima sakyti, kad naujasis mokslas nagrinejja tai, ko nelietè klasikinis mokslas, kuris visur stengèsi ieškoti idealios tvarkos, tikslių priežastinių ryšių, absoliutaus aiškumo ir objektyvumo. Šiuolaikinis mokslas yra žmogiškas, o ne „dieviškas“ fenomenas. Ir visos senojo mokslo viltys matyti visiškai objektyvu, racionalų ir neginčijamais faktais grịstą mokslą dabar subliūško dèl naujojo mokslo laimèjimų. O didžiausias naujojo mokslo (SDS mokslo) laimejjimas - tai realus supratimas, ką gali ir ko negali mokslas.

SDS paradigmos esmę sudaro:

- Subjekto žinių kuklumas, nes nežinojimas mus tikrai visus padaro lygius. Šito žinojimas sustabdo nuo išankstinio ir baigtinio žinojimo, kurio negali būti.

- Tiesos ieškojimo plokštumas, grubumas. Tiesos paieška yra veiksmingesnè, kai einama ne prie dalies, bet prie visumos ir prie pagrindinių visumos savybių. Kitaip tariant, SDS paradigma labiau remiasi holizmu nei klasikiniu redukcionizmu.

- Lokalios priežasties išnykimas, nes priežastis veikiau yra globali.

- Iš principo negalima tiksliai nustatyti SDS pradinès būsenos (neapibrèžtumo principas). Nèra objektyvių savybių, kurios visiškai nepriklausytų nuo subjekto silpnybių.

\section{SUDE்TINGOJI DINAMINE் SISTEMA: KAS TAI?}

SDS - tai sunkiai žmonėms suprantama sistema, kurios pagrindiniai bruožai yra daugelio jos dalių kintami tarpusavio ryšiai ir dèl to dažniausiai kylanti nuolatinè sistemos savybių kaita. Pasaulis dažnai randasi spontaniškai, netiesiškai ir būtinai originaliai, atsižvelgdamas ne tik į savo vidini tikslą, bet ir į aplinkos spontaniškas išdaigas (Bak, 1996; Bar-Yam, 2004; Maturana, Varela, 1998; Strogatz, 2003; Skytner, 2006). Štai kodèl dabartiniu metu pasaulio intelektualai (tarp ju ir teisininkai) yra pasimetę, kaip patikimiau nustatyti tiesą ir teisingumą. Todẻl mažai abejotina, kad 
yra keletas konkuruojančiu tiesos ir teisingumo nustatymo teorijų teisès srityje: prigimtinès teisès, teisinio pozityvizmo, teisinio realizmo, integruotos teisès, postmodernizmo ir kitos (Coleman, Leiter, 1999; Kelsen, 2002; Posner, 2004; Dworkin, 2005; Patterson, 2008).

Jei pasaulis (realybè) būtų kaip tiksliai veikianti mašina, tada mokslo tikslas būtų aiškus: pažinti tos mašinos dalis ir mechanizmus. Tuomet žinotumėme, kaip veikia pasaulis. Visgi, kaip parodè pastarujų dviejų dešimtmečiu mokslo laimejjimai (SDS tyrimo rezultatai), pasaulis nèra tiksliai veikianti mašina (Marshall, Zohar, 1997; Prigogine, 1997; Skytner, 2006), todèl tiek biologijos, tiek teisès srityje dabartiniu metu nèra populiarios deterministinès pažinimo paradigmos. Pastaruoju metu negailestingai kritikuojama teisinio pozityvizmo teorija teisès srityje, nes pagal ją teisingumas teisinèje sistemoje yra nustatomas pagal griežtai apibrèžtas taisykles, atmetant žmogiškaji veiksni (Coleman, Leiter, 1999). Pasirodo, neịvertinus socialinio konteksto, moraliniu vertybių ir sveiko proto principų negalima suvokti, kas yra teisinga ir kas ne. Nèra ir negali būti tiesos bei teisingumo nustatymo „mašinos“, kurios veikimas nepriklausytų nuo žmogaus (jo patirties, kultūros, ideju, išsilavinimo, moralès ir pan.).

Galima sakyti, kad chaosas ir tvarka sugyvena sudetingose sistemose, nepaisant to, kad tarp ju vyksta nuolatiniai nesutarimai. Kitaip tariant, SDS prarastų savo esmę, jei iš jos išimtumème tvarką ar chaosą. Šios poros - tvarkos ir chaoso - sąveika ir yra pagrindinis SDS gyvenimo mechanizmas. Tokiu poru SDS yra kur kas daugiau, pavyzdžiui, stabilumas ir kintamumas, logika ir paradoksas, universalumas ir unikalumas, kooperavimasis ir konkurencija. Mokslininkams teks dar nemažai padirbėti, kol nustatys šių (ar kitų) priešingų poru sąveikos mechanizmus ịvairiose kompleksinèse sistemose.

Galima skirti šiuos pagrindinius SDS elgsenos bruožus:

- Sistemos, kurios mokosi ir treniruojasi, veiksmingiau išgyvena.

- SDS geba toleruoti tam tikras sistemos klaidas ir yra iš dalies atsparios išoriniam poveikiui.

- Sistemos stabilumas padideja, kai jos dalys tampa gana savarankiškos ir bendrauja be itampos.

- Kad sistema išgyventų, ji turi dažnai keisti aplinka.

- Sistemos gyvybingumo principas: gebejjimas iškęsti aplinkos pokyčius.

- Per didelè sistemos specializacija gali trukdyti kaitai.

- Informacija sistemos viduje plinta greičiau negu tarp sistemu.

- Sistemos dalis paklūsta sistemos tikslui tik tada, kai ji yra paskatinama ir nebaudžiama.

- Sistema gali evoliucionuoti ir i visuma, ir i gyli.

- Entropijos dėsnis: uždarosios sistemos entropija dideja.

- Papildomumo principas: sistema turi būti tiriama daugeliu būdų.

- Reikalaujamos ivvairovès dèsnis — valdytojas turi būti įvairesnis nei valdomasis ar valdoma situacija.

- Reikalaujamos hierarchijos dèsnis: kuo silpnesnè sistema, tuo daugiau biurokratinių valdymo lygių.

- Sinergijos principas: sistemos dalys viena kitai padėdamos bendrai siekia tikslo.

- Neapibrèžtumo principas: sudėtingos sistemos būsenos visiškai tiksliai vienu metu negalima nustatyti.

\section{SDS DE்SNIAI}

SDS elgsenos galimybių ir tikimybių kaita. Naujojo mokslo paradigma ragina ị pasauli žiūrèti galimybių ir jų reiškimosi tikimybių kaitos akimis (Prigogine, 1997; Laughlin, 2005). Pasaulyje kur kas daugiau galimybiu nei realybių. Kiekviena galimybė yra potenciali realybė ir jos (galimybès) tapimas realybe priklauso nuo daugelio veiksnių, kurių visų įvertinti neịmanoma. Pasirodo, kad kurios nors SDS savybės reiškimosi tikimybè yra kintama, t. y. kintanti laike. Klasikinio mokslo paradigma pripažino tik būtinumo svarbą, o naujojo mokslo paradigma leidžia manyti, kad kiekvieno ivykio pasireiškimas priklauso nuo tam tikros tikimybès ir atsitiktinumu. Galima sakyti, kad SDS savybės konkreti reikšmė visada pasireiškia tik tam tikra tikimybe.

SDS elgsenai būdingas negrị̌tamumas. Anot I. Prigogine (1997), negrižtamumas - tai naujos tvarkos ir pažangos šaltinis. Kitaip tariant, dèl nestabilumo, asimetriškumo ir neišvengiamų klaidu SDS elgsena turi savo laiko strèlę, kuri nukreipta tik i ateiti. Žiūrint naujojo mokslo paradigmos akimis, tas pats gamtai keliamas klausimas turès skirtingą atsakymą, nes ji nuolatos keičia savo būvi. Todèl SDS būsena visados yra kitokia. SDS elgsenos kryptis yra sudètinga, nes ji juda i va- 
dinamaji sudètingą atraktorių. Taip judėdama, ji užima naujas erdves. Tai yra SDS globalizacijos vyksmas. SDS globalizacija - tai nauji ryšiai ir sąveika su aplinka. Dèl negrižtamų vyksmų SDS turi unikalią savybę - gebèjimą mokytis.

Pradinès būsenos jautrumas atsitiktinumams („drugelio efektas"): ar tikrai maža klaida dauginasi? Vienas iš svarbiausių SDS bruožų - maža paklaida pradinèje sistemos sąlygoje lemia milžiniškus galutinès sistemos būsenos pokyčius. Ši fenomeną Lorencas (1963) pavadino drugelio efektu. Šis Lorenco atradimas paneigè P. S. Laplaso (Laplace Piere Simon, 1749-1827) determinizmo principa, teigianti, kad bet kurios sistemos elgseną (evoliuciją) iš principo galima apskaičiuoti, kai žinomos pradinès sistemos sąlygos. Naujojo mokslo paradigma aiškina, kad iš principo negalima absoliučiai tiksliai prognozuoti SDS elgsenos, nes negalima absoliučiai tiksliai išmatuoti SDS būsenos. Anot naujojo mokslo paradigmos, atsitiktinumas ir chaosas turi didelę reikšmę aiškinant SDS visumos elgseną. Kitaip tariant, naujojo mokslo paradigma mus ispejja, kad smulkmenų ašmenys aštrūs - kiekviena mums atrodanti smulkmena dažnai nėra smulkmena, nes ji gali daugintis ir sukelti neprognozuojamų visos sistemos elgsenos pokyčiu (Prigogine, 1997; Strogatz, 2003; Laughlin, 2005).

Sudètingųjų dinaminių sistemų kintamumas. Kiekvieną kartą SDS dalių sąveika sukuria originalią elgsenos savybę (savybių i̇vairovę) (Holland, 1998; Noble, 2006). Kitaip tariant, niekados nebepasikartos tokia pat praeitis. Naujojo mokslo paradigma mus íspejja, kad pagal praeiti negalima tiksliai prognozuoti ateities, kaip ir dabarties pažinimas neleidžia suprasti praeities, nes niekas negali pažinti visų galimų buvusių, esamų ar būsimų sąveikų. SDS elgsena kinta sudėtingai: kai priežastis ir padarinys nèra artimi laiko bei erdvès požiūriu ir kai akivaizdi priežastis nesukelia lauktu padarinių, nes kintamai, spontaniškai, ịsiterpia kiti nenumatyti (ar nenumatomi) veiksniai. Mokslininkai dar yra tik kelionès, kurios tikslas — pažinti dalių sąveikos dèsningumus, pradžioje. Nors tai tik pradžia, tačiau mums visiems pravartu suprasti, kad iš keleto paprastų taisyklių kiekvieną kartą susiformuoja vis kitoks SDS ,žaidimas“ (Kauffman, 2000; Strogatz, 2003).

Smèlio pilies fenomenas - SDS tvarkos kūrimo ir palaikymo mechanizmas. SDS elgsenai būdinga savireguliuojanti krizè (Bak, 1996). Kitaip tariant, SDS turi savireguliuojančią jègą, kuri, kaip manoma, inicijuoja ir palaiko SDS judèjimo kryptị arba pagrindinę funkciją, kaip ir smèlio pilis pastatoma iš atskirų smiltelių. Šis tvarkos kūrimo ir palaikymo mechanizmas leidžia SDS atsikratyti pertekliaus ir, jei reikia, atnaujinti trūkstamas dalis. Todèl SDS krizè - tai neišvengiama tokiu sistemų elgsenos savybè (Bak, 1996). Kuo labiau sistema kinta, tuo labiau pasireiškia savireguliuojanti krizè. Reikia suprasti, kad SDS kriziu išvengti negali ir negalès. Kiekvienas bandymas jas sureguliuoti iš išorès yra tik bandymas krizę atitolinti, o ne pašalinti jos galimybę. Didžioji tvarka atsiranda iš deterministinio chaoso, o didysis chaosas kyla iš stagnacijos. Deterministinis chaosas - tai chaosas, kuris kyla iš sistemos daliu ir jų priežastinių ryšiu (sąveikos) su aplinka. Kitaip tariant, tai neprognozuojama tvarka, kuri kyla iš aiškių ir apibrēžtų mechanizmų.

Kadangi SDS turi susireguliuojančią jèga, ji nemėgsta, kad kas nors ją valdytų iš išorès (Strogatz, 2003; Noble, 2006). Galima sakyti, kad SDS valdoma iš vidaus. Susireguliavimas dažnai vyksta spontaniškai ir pagal kitą scenariju, tačiau tai nereiškia, kad SDS nereaguoja i aplinkos pokyčius. Galima teigti, kad jei šiuolaikinè visuomenè elgtųsi vien tik pagal įstatymus ir nesivadovautu moralès, sveiko proto principais bei vertybemis, tada visuomeneje kiltu tikras chaosas. Gyventi teisineje visuomeneje nereiškia vadovautis tik tuo, kas parašyta Konstitucijoje. Visuomenès elgseną stabilizuoja ne tik istatymai, teismai, bet ir visuomenès moralinès vertybès, papročiai, sveikas protas (Posner, 2004; Dworkin, 2005).

\section{SDS TYRIMO METODOLOGIJA}

Ar galima sudėtingą pasaulị paaiškinti paprastai? Dalis mokslo genijų šiuo metu vis dar nepraranda vilties, kad kada nors bus sukurta visas teorijas integruojanti teorija, galinti paaiškinti milžinišką realybès ịvairovę. Deja, nepaisant geniju pastangu, tokia teorija lieka tik vizija. SDS paradigmą pripažistantys mokslininkai, atrodo, nèra nusiteikę ieškoti ar kurti tokios ,vieningos“ teorijos, nes seniai pastebejjo, kad realybès iqvairovẻ negali būti kildinama iš vieno požiūrio, teorijos, dèsnio ar principo.

SDS tyrimo paradigma ragina realybę tirti ne viena, bet daugeliu metodologijų. Kadangi pasaulio realybė yra labai sudètinga ir nuolat kintanti, norint ją pažinti, kaip teigia I. Prigogine (1997), būtina su realybe kalbètis daugeliu kalbų. Naujojo mokslo paradigma ragina mokytis gamtos (SDS) kalbų, nes kalbos su mumis šnekasi ne vie- 
na, bet tūkstančiais kalbų. Be to, SDS paradigma ispejja, kad vienpusiškai tiriant sudètingąsias dinamines sistemas beveik visados ištinka nesėkmè. Todèl SDS reikia tyrinèti iš iqvairiu pusių, nes ji yra daugiareikšmé, kintanti, spontaniška. Gamta, galima sakyti, niekados nemeluos, jei ją tiksliais klausimas , „ivarysi i kampą“. Todèl, norint aiškiau suprasti SDS elgsenos ypatumus, būtina naudotis ne viena, bet daugeliu metodologijų. Net yra siūloma visiškai nesusižavèti pažinimo metodologijomis (Feyerabend, 1975).

Ceteris paribus. Naujoji mokslo paradigma ištaisè vieną didžiausių klasikinio mokslo klaidų sukritikavo teiginio Ceteris paribus (lot.) galią. Teiginio Ceteris paribus lietuviškas atitikmuo „kai kitos sąlygos (aplinkybės) yra tos pačios“ (Drewery, 2001). Klasikinio mokslo paradigma teigia, kad kuris nors fenomenas egzistuota taip ir tada, tik esant toms pačioms sąlygoms. Šis teiginys buvo ir, deja, yra pagrindinis pleištas, suskaldęs tikrovę i milijoną atskirų dalių, kurių surinkti, kad gautumei tikrovę, beveik neįmanoma.

Ar naujojo mokslo paradigma pakeitè mokslo misiją? Priešingai klasikinio mokslo paradigmai, naujojo mokslo paradigma supranta, kad mokslo misija - tai greičiau kelione, o ne atvykimas. Todèl, anot naujojo mokslo paradigmos, mokslo pagrindinis tikslas - ne atskleisti universalią tiesą, nes to padaryti neimanoma, bet artèti prie didesnio realybès supratimo aiškumo, kartu parodant jos daugiareikšmiškumą — sudètingumą (Popper, 1959; Prigogine, 1997; Laughlin, 2005; Skurvydas, 2008). Naujojo mokslo paradigma ragina būti kuklesniais, t. y. drąsiau prisipažinti, kad mūsų žinojimas yra kur kas mažesnis už nežinojimą. Paradoksas: kuklumo stoka moksle, kaip ir perdètas kuklumas, sulètina artèjimo prie tiesos spartą.

SDS elgsenos dèsningumas gali būti suprantamas tik kartu su kitais dèsningumais. Kiekvienas désnis veikia tik kartu su kitais désniais. Jei yra koreguojamas vienas iš dèsnių, būtinai turi būti peržiūrimi ir kiti (Prigogine, 1997; Laughlin, 2005). Galima sakyti, kad daugelis dèsniu yra susiję daugybe saitų, kurių vieno pajudinimas pakeičia visą dèsnių struktūrą.

Kiekviename teiginyje yra tiesos ir netiesos „grūdų“. Kuo daugiau tiesos gabalèlių teiginyje, tuo šis teiginys yra arčiau tiesos, bet iš jo niekados nebus visiškai ,išvalyta“ netiesa, nes tiek objektas, tiek subjektas nestovi vietoje, o keičiasi ir dažniau darydamasis vis sudètingesnis, artėdamas prie didesnès entropijos, nepaisant to, kad tam tikru momentu, atrodo, viskas aišku. SDS paradigma pabrèžia, kad visas pažinimas darosi hipotetinis: jo teiginiai gali būti teisingi, bet jie visada iš principo gali būti peržiūrimi ir kada nors jų gali būti atsisakyta. Todèl suprantama, kad nuolatinè abejonè prasiskverbia i kasdieni gyvenimą ir mokslą.

Ar mokslinè tiesa priklauso nuo mokslo paradigmos? Vis labiau suprantama, kad silpnoji mokslu vieta yra ne jų specifiniai metodai ir igūdžiai, bet jų metodologijos, bendroji mokslo kultūra (paradigma) ar visos mokslo bendruomenès kultūra. Jei būsime ištikimi mokslo vertybėms ir principams, jis (mokslas) gali mums nurodyti, kada mes klystame ir kada iš tikrujų esame teisūs. Tai dar vienas argumentas, kodèl mokslo galia labai daug priklauso nuo mokslo bendruomenès mąstymo paradigmos (kultūros, vertybiu).

Naujo supratimo būtina sąlyga - tai supratimas, ko nesupranti. Pasak G. M. Weinberg (2001), naujo supratimo (sužinojimo) pradžios būtina sąlyga yra supratimas, ko nesupranti. Todèl, kai aš teigiu, kad viską suprantu, tai iš tikrujų reiškia, kad aš nieko nauja nesuprantu. Todèl pirmiausia turetume sutikti, kad moksle yra nepalyginamai daugiau klausimų nei atsakymų. Pavyzdžiui, savęs nei kitų neturètume klaidinti teigdami: „tuoj tuoj palaukite, ir mes gebėsime išgydyti žmones nuo bet kurios ligos". Tai yra deterministinis mąstymas (senojo mokslo mąstymas).

Ar mokslas yra visagalis? O kaip teisè? Vienas svarbiausių mokslo tikslų, pasak medicinos mokslo Nobelio premijos laureato P. Medawar (1988), yra stengtis suprasti, ką gali ir ko negali mokslas. Mokslo galia yra daug mažesnè, lyginant ją su mus supančiu neaiškumu. Mokslas visų žmonijos problemų negali išspręsti (Feyerabend, 1975). Visgi kaip sužinoti, kokius darbus turi atlikti mokslas ir kokiems darbams jis nèra pasirengęs (o tik yra „Molio Motiejus"), kaip teigia H. Collins ir T. Pinch (1993)? Čia padeda sveikas ir kritiškas protas. Kaip bebūtu gaila, šiuolaikinis mokslas dažnai linkęs užsidaryti savo kiaute.

Visuomenè iš mokslo neturi reikalauti nematytų stebuklų (nors dažnai atrodo, kad mokslas yra stebukladarys). Kuo labiau išprususi visuomenè ir labiau supranta, kas tai yra mokslas, tuo daugiau ji su mokslu šnekasi paprastesne ir realesne kalba. Mokslas nebus apšauktas nevykèliu, jei jis neparodys stebuklų. Kad tai įvyktų, būtina jau bendrojo lavinimo mokyklose supažindinti moksleivius, ką realiai gali ir ko negali mokslas. Dabar mokyklose moksleiviai mokami didžiulès netiesos, būtent, kad mokslas gali viską. Dar prie to dažnai prisi- 
deda ir universitetai, kurie pagal savo misiją tikrai to neturetų daryti.

Ar mokslo filosofija gali padėti atrasti ir (ar) sukonstruoti tiesą? Mokslo filosofai nagrinèja, pasak A. Rosenberg $(2000,2007)$, dviejų tipu klausimus: a) i kuriuos negali atsakyti fizikai, biologai, medikai ar socialiniu bei humanitariniu mokslų mokslininkai; b) klausimus apie tai, kodèl negalima atsakyti i pirmo tipo klausimus. Taigi mokslo filosofai nagrinejja tą realybès (tikrovès) dalị, kurios nenagrinejja specialiujų mokslo sričiu mokslininkai. Galimi du aiškinimo variantai: a) specialiujų mokslų mokslininkai neturi pažinimo instrumentų, leidžiančių tirti (pažinti) tą realybès dali, kurią tiria mokslo filosofai; b) mokslo filosofija nenagrinèja realybès, o tik kelia bendruosius klausimus apie realybę.

Specialieji mokslai dažnai nemėgsta metafizikos, nes ji yra mąstymas apie bendruosius realybès principus, prie kurių retai specialieji mokslai prisiliečia. Tačiau mokslo filosofija kelia labai daug metafizinių klausimų, kurių atsakymais naudojasi ir specialieji mokslai. Taigi ar pelnytai specialieji mokslai nemėgsta metafizikos? $\mathrm{Ne}$, nes dažnai vieni iš geriausių fizikų ar biologų sutaria su metafizika.

Mokslinès tiesos konstravimo iracionalumas - tai pagrindinis skirtumas tarp mokslinès tiesos ir teisingumo nustatymo teisès srityje. Naujojo mokslo požiūriu, mokslinè tiesa dažniausiai neatrandama realybejje (tikrovèje), bet sukonstruojama (Van Fraassen, 2001). Kiekvienas mokslininkas ją konstruoja savaip, bet dalyvaujant visai mokslo bendruomenei, kuriai „vadovauja“ jos pačios priimta mąstymo paradigma. Kitaip tariant, mokslo bendruomene negali priimti labai originalių tiesų, nes tai neatitiktu jos (bendruomenès) mąstymo standartų. Šis tiesos konstravimo būdas yra vadinamas konstruktyviuoju empirizmu (Van Fraassen, 2001). Norint sukonstruoti tiesą apie realybę, būtina pasitelkti ì pagalbą dèsnius, teorijas, modelius, paradigmas, sveiką protą. Kas yra pagrindinis konstruktorius? Mokslininkas, padedamas mokslo bendruomenès. Iš kokių komponentų yra konstruojama tiesa? Iš empirinių faktų, „plytu““? Tada yra sukuriama realybè. Silpniausia konstravimo dalis yra ta, kad trūksta labai daug tikruju „plytų“ ir vietoje jų reikia dažnai naudotis nepatikrintomis, o ,plytas“ rišantis „skiedinys“ logika - ne visada yra patikima. Kitaip tariant, šių dienu mokslininkai „pastato“ labai grubų, dažniausiai skylètą „namą“, kurị mes ir vadiname moksline tiesa, dèsniu, teorija ar modeliu. Toks tiesos konstravimo būdas dažnai priskiriamas moksliniam realizmui (Psillos, 1999). Mokslininkai, pripažįstantys mokslini realizmą (taip, kaip teisininkai, kurie remiasi teisiniu realizmu), tiki, kad teorijos, netiesioginiu būdu aprašančios daugelị empirinių fenomenų, gali būti teisingos.

Dažniausiai nei patys mokslininkai, nei visuomenè nèra patenkinti tokiu kūriniu. Tada ji tobulina arba visiškai nugriauna. Jei „namas“ šiek tiek pasisekè, jis išsilaiko gana ilgai (namo pamatai išlieka dar ilgiau). Tada mes tai vadiname fundamentaliomis tiesomis tol, kol kita žmonių karta jas perkonstruoja arba sukonstruoja visiškai iš naujo (ant naujų pamatų). Taigi ar tai tikrai yra fundamentalios tiesos? Abejoju.

Vadinasi, mokslininkai konstruoja tiesą iš nepatikimu ,plytu“" ir tai prisipažista, o teisininkai nustato teisingumą dažnai iš tokių pat „plytų“, tačiau teisès srityje (dèl patogumo žmonèms) tai yra vadinama teisingumu. Ar tikrai taip gali būti? $\mathrm{Ne}$, tačiau kaip stabilizuoti visuomenę, jeigu jai nepasakome to, ko ji nori - absoliučios tiesos?

Naujasis redukcionizmas ir naujasis holizmas. Naujojo mokslo paradigma neigia klasikinio redukcionizmo galia ir ragina labiau pažinti ne SDS dalis, bet jų sąveiką (ne namo plytas, bet konstrukcijas) (Rose, 1998; Laughlin, 2005). Redukcionizmas tinka tik atskiroms dalims pažinti, bet ne visumai, nes SDS visumos elgsenos savybė yra daugiau negu jos dalių suma. Todèl iš SDS visumos negalima spręsti apie jos dalị, kaip ir iš dalies elgsenos negalima suprati visumos. Jeigu pažisstame daugiau detalių, dar nereiškia, kad daugiau žinome.

Naujasis redukcionizmas ragina pažinti visumos dalių sąveiką, nes tik taip bus galima suprasti, kaip veikia visuma (Noble, 2008). Klasikinis holizmas (jis yra mažiau populiarus nei klasikinis redukcionizmas) akcentuoja ne visumos dalių elgsenos pažinimą, bet visumos elgseną. Jis teigia, kad visuma - tai nèra dalių suma, todèl norint suprasti visumos elgsenos ypatybes nebūtina suprasti, kaip veikia jos dalys. Naujasis holizmas sujungia holizmą ir naujaji redukcionizmą — remiantis daliu sąveikos ypatybemis (mechanizmais) stengiasi pažinti (paaiškinti) visumos elgsenos ypatybes (Noble, 2008). Pagrindinis klasikinio holizmo trūkumas - tai visumos sandaros nepažinimas. Holizmas skatina pažinti visumą, o ne vidines priežastis arba pagrindinę idejją kuri sujungia dalis ir formuoja visumą. Kitaip tariant, holizmas neskatina pažinti iš vidaus - jis akcentuoja „paviršių“, forma. Kartais ir tai padeda. 
Naujasis redukcionizmas neneigia, kad norint pažinti visumos elgseną reikia suprasti jos daliu savybes, tačiau jis labiau akcentuoja ne atskiru dalių elgsenos dèsningumus, bet dalių sąveikos ypatybes. Todèl galima sakyti, kad naujasis redukcionizmas - tai visumos daliu sąveikos laike ir erdvejje mokslas (Rose, 1998). Be to, naujasis redukcionizmas skatina gilintis ne į visumos daliu „vidutines“ savybes, bet ị savybiu ivvairovę, net nebijant jų „triukšmo“. Taigi naujasis redukcionizmas yra labai atsargus atmesdamas nestandartines kintamuju reikšmes, nes gali pasirodyti (taip dažnai yra), kad tokie ,atsitiktinumai“ labai svarbūs aiškinant gyvujų sistemų elgsenos fenomenus.

Mokslininkai turi klausimu ne vien klasikiniam holizmui ir redukcionizmui, bet ir naujajam redukcionizmui bei naujajam holizmui. Būtent neaišku, ar galima remtis dalių sąveikos mechanizmu kaip elementariausia (fundamentalia) naujojo holizmo „plytele“? Be to, tikrai neaišku, kiek ir kada pakanka vien tik dalių sąveikos pažinimo, o kada neišvengiamai reikia dar labiau smulkinti visumos dalis. Tuo labiau neaišku, kaip nustatyti, kiek pakanka pažinti sąveikų, kad galètume suprasti, kaip veikia visuma.

Yra labai daug realybės lygių, kurie vienas iš kito tiesiogiai neišvedami. Antai iš fizikos tiesiogiai neišvedama chemija, iš chemijos - biochemija, iš biochemijos - fiziologija, iš fiziologijos - psichologija, iš psichologijos - sociologija, iš sociologijos - teisè ir t. t. Todèl klasikinis redukcionistinis požiūris ieškant pačios giliausios tiesos, iš kurios būtu galima išvesti kitas tiesas, netinka, kai šnekame apie skirtingus realybès lygius. Taip pat netinka ir klasikinis holistinis požiūris, kai tiriamas fenomenas yra suprantamas tik kaip ji sudarančiu elementų visuma. Todèl dabartiniu metu mokslininkai bando sujungti du skirtingus požiūrius - redukcionizmą ir holizmą. Nepaisydami sunkumų ir sujungdami dvi priešingas idèjas, mokslininkai sèkmingai taiko naujaji holizmą ir naujaji redukcionizmą, kurie akcentuoja „dvigubą žvilgsnį“ i realybę. Kai tiriama dalis, tuo pačiu fiksuojama ir jos vieta visumoje; kai tiriama visuma, tada ją stengiamasi suprasti kaip jos sąveiką su dalimis.

Kuo sudètingesnè ir kintamesnè sistema, tuo sunkiau ją perprasti: ar tikrai? Pačios sudetingiausios ir kintamiausios sistemos (pvz., abstrakčiosios) yra dažniausiai sukonstruotos iš netiesioginių faktų. Kuo sudètingesnè ir kintamesnè sistema yra tiriama, tuo sąžiningesni turi būti mokslininkai, nes jie mokslinę tiesą konstruoja remdamiesi sveiku protu, spejjimu, hipoteze, patirtimi, intuicija, logikos taisyklèmis ir tiesioginiais bei netiesioginiais faktais. Štai kodèl fizikos mokslas dažnai kreivai žiūri i socialinius mokslus. Bet tai - laiko klausimas: fizikas supras, kad jo akimis negalima žiūrèti i socialines sistemas, o socialinių sistemų tyrejjas išmoks atsargiau interpretuoti mokslinius faktus. Teisès srityje yra žinomos sunkios (sudètingos) bylos, kuriose gana keblu nustatyti teisingumą. Visų sudètingujų dinaminių sistemų pažinimas yra toks pat sudettingas, kaip ir sunkių bylų išnarpliojimas teisès srityje. Sunku patikèti, kad teisèjai nedaro šiose bylose klaidų, nes mokslininkai, tirdami sudètingus fenomenus, dažniau klysta nei atranda ir nustato tiesą. Skirtumas tarp teisejų ir mokslininku yra tas, kad mokslininkai gali klysti, o teisèjas ne.

\section{KAS AUKŠČIAU: ISTATYMAI AR MORALÉ?}

Nors, atrodo, teisingas atsakymas galètų būti, kad ir įstatymai, ir moralè yra vienodo svarbumo, dažniausiai atsakymas ị ši klausimą priklauso nuo to, kokia teisès paradigma (teorija) vadovausis atsakovas. Teisinis pozityvizmas (kaip moksle loginis empirizmas) remiasi teisinėmis taisyklèmis ir ragina griežtai jų laikytis, nors tai prieštarautų moralinėms vertybèms ir sveikam protui. Prigimtinès teisès atstovai žmogaus moralines vertybes iškelia aukščiau taisyklių. Teisinio realizmo (kaip ir integralios teisès teorijos) puoselètojai ieško atsakymo vidurio, postmodernistai negailestingai kritikuoja bet koki griežtai nustatytą principą, taisyklę ar vertybę. Visoms šioms teorijoms geriau susiorientuoti gali padèti naujojo mokslo - sudètinguju dinaminiu sistemų tyrimo - paradigma.

\section{SDS TYRIMO PARADIGMA: BŪTINYBE் AR MADA?}

Atsakymas: iš pradžių buvo būtinybè, vèliau ja pasekè „stilingieji“, kurių dabar yra kur kas daugiau nei tų, kurie iš esmès nori pažinti SDS. SDS paradigma šiuo metu sukuria vieną, bet labai didelę blogybę - naujos mados (sistemų kintamumo) suvilioti mokslininkai dažnai šneka sudėtingujų sistemų kintamumo kalba, jos visiškai nesuprasdami. Bet kaip išmoksi ,gamtos kalbos“, jei su ja nekalbėsi? Dar kitaip tariant, gamta su mumis „kalba“" pasitelkdama daug kalbų, ir mes nebūtinai turime (nors norètųsi) jas visas mokèti. 
Jei nemokame naujos - sudètinguju dinaminiu sistemu — kalbos, tai gamtą kalbinkime anksčiau išmokta kalba. Kaip teisès srityje sujungti skirtingas teisingumo įvertinimo teorijas: prigimtinès teisès, teisinio pozityvizmo, teisinio realizmo, integruotos teisès teorijos, postmodernizmo? Tai gana sunku, nes dažniausiai skirtingų paradigmu (teorijų) aiškinimo negalima iš principo palyginti - jos remiasi savo kriterijais ir aiškina tiesą savaip (ir dažnai net teisingai) (Kuhn, 1970). Blogiausia, kas gali atsitikti mokslininkui, yra tai, kad jo „labai madingos kalbos“ nesupranta gamta. Tada lieka tik monologas, kurio rezultatas - pseudomokslas. Dar viena problema - galima kelti „gamtai“ teisingus ir jai suprantamus klausimus, bet ji tyli arba, jei ir kalba, mes jos negirdime. Vadinasi, žmogui vienas iš sunkiausiu klausimu yra: iš kur jis žino, kad žino? Kada žmogui yra gana, jei apskritai tai būna pažinimo kelionejje? O kas tai žino? O gal jis net ir nežino, kad nežino? Didžiausias aiškumas — žmogui niekados nèra gana pažinimo kelionėje. Galbūt ir tai yra klaida? Jei ne klaida, tai pats metas yra mokytis naujojo mokslo (sudètingujų dinaminiu sistemu tyrimo) kalbos. $\mathrm{O}$ ar dèl to atsiras daugiau teisingumo mūsų gyvenime. Greičiausiai, kad taip.

\section{IŠVADOS}

Šių dienų pasaulyje vyksta mokslo paradigmos kaita. Vyksta pasaulěžiūrų sankirtis. Dabar naujasis mokslas „verčia“ senaji mokslą. Viena iš didžiausių senojo mokslo klaidų yra ta, kad jis išskyre griežtas ribas tarp mokslų. Todèl atsirado labai daug atskiru mokslo „specialistuc“ ir mažai kas besupranta, kas iš tikruju yra mokslas. Kovoja, nors tai dažnai sunkiai ižiūrima, senasis (deterministinis ir mechanistinis) mąstymas, pagrịstas visiško aiškumo ir objektyvumo siekiu, su naujuoju — sudètinguju (kompleksiniu) dinaminių sistemų paradigma, kuri nesuabsoliutina pažinimo galimybiu ir vis labiau supranta, kad kiekvienas pažinimas priklauso ne tik nuo subjekto pažinimo ribotumo, bet ir nuo objekto sudetingumo, kintamumo, t. y. negalimumo iš principo ji tiksliai pažinti, ištirti, suprasti. Kas laimi šiuo metu? Nèra abejonès, kad senasis, labiau patyręs ir daugiau „užtarejju“ turintis mokslas. Tačiau pergalè yra gana trapi, nes ivvairių mokslų lyderiai vis drąsiau kelia senojo mokslo trūkumus ir rodo naujojo privalumus. Štai kodèl pats metas iš esmès peržiūrèti ne tik mokslinių tyrimų paradigmas, bet ir tiesos bei teisingumo nustatymo teorijas (paradigmas) teisès srityje. Naujasis mokslas neabejotinai daug kuo gali padidèti šiuolaikinei teisei.

\section{LITERATŪRA}

Bak, P. (1996). How Nature Works: The Science of Self Organized Criticality. New York: Copernicus, SpringerVerlag.

Bar-Yam, Y. (2004). Making Things Work: Solving Complex Problems in a Complex World. NESCI: Knowledge Press.

Burggren, W. W., Monticino, M. G. (2005). Assessing physiological complexity. Journal of Experimental Biology, 208, 3221-3232.

Coleman, J., Leiter, B. (1999). Legal Positivism. In D. Patterson (Ed.), A Companion to Philosophy of Law and Legal Theory. New York: Blackwell Publishing. P. 241-260.

Collins, H., Pinch, T. (1993). The Golem: What Everyone Should Know About Science. Cambridge: Cambridge University Press.

Drewery, A. (2001). Dispositions and ceteris paribus laws. British Journal for the Philosophy of Science, 52, $723-733$

Dworkin, R. (2005). Teisès imperija. Vilnius: Rašytojų sajungos leidykla.

Elster, J. (2007). Explaining Social Behavior: More Nuts and Bolts for the Social Sciences. $1^{\text {st }}$ edition. Cambridge: Cambridge University Press.

Feyerabend, P. (1975). Against Method. London: Verso.

Forrester, J. W. (1971). World Dynamics. Cambridge, Massachusetts: Wright Allen.
Van Fraassen, B. (2001). Constructive empiricism now. Philosophical Studies, 106, 151-170.

Gell-Mann, M. (1994). The Quark and the Jaguar: Adventures in the Simple and the Complex. San Francisco: W. H. Freeman.

Gleick, J. (1987). Chaos: Making a New Science. Viking: Penguin (Non-Classics).

Goodwin, B. (2001). How the Leopard Changed its Spots. The Evoliution of Complexity. New York: Princeton University Press.

Von Hayek, F. A. (1998). Teise, istatymu leidyba ir laisve: taisyklès ir tvarka. T. 1. Vilnius: Eugrimas.

Holland, J. H. (1998). Emergence: from Chaos to Order. Cambridge, Massachusetts: Perseus Books.

Kauffman, S. A. (2000). Investigations. Oxfrod: Oxford University Press.

Kelsen, H. (2002). Grynoji teisès teorija.Vilnius: Eugrimas.

Kuhn, T. S. (1970). The Structure of Scientific Revolutions. Chicago: University of Chicago Press.

Laszlo, E. (2002). The Systems View of the World: A Holistic Vision for Our Time. Hampton Press, Inc.

Laughlin, R. B. (2005). A Different Universe. Reinventing Physics from the Bottom down. New York: A member of the Perseus Books Group. 
Marshall, I., Zohar, D. (1997). Who's Afraid of Schrodinger's Cat? An A-to-Z Guide to All the New Science Ideas You Need to Keep up with the New Thinking. New York: Quill William Morrow.

Maturana, H., Varela, F. J. (1998). The Tree of Knowledge. The Biological Roots of Human Understanding. Boston and London: Shambhala.

Medawar, P. (1988). The Limits of Science. Oxford: Oxford University Press.

Noble, D. (2008). Claude Bernard, the first systems biologist, and the future of physiology. Experimental Physiology, 93 (1), 16-26.

Noble, D. (2006). The Music of Life. Biology Beyond the Genome. Oxford: Oxford University Press.

Patterson, D. (2008). Postmodernism. In D. Patterson (Ed.), A Companion to Philosophy of Law and Legal Theory. Oxford: Blackwell Publishing. P. 375-384.

Popper, K. R. (1959). The Logic of Scientific Discovery. London: Routledge.

Posner, R. A. (2004). Jurisprudencijos problemos. Vilnius: Eugrimas.

Prigogine, I. (1997). The End of Certainty. Time, Chaos, and New Laws of Nature. Oxford: The Free Press.

Psillos, S. (1999). Scientific Realism: How Science Tracks Truth. London and New York: Routledge.
Rosenberg, A. (2000). Philosophy of Science: A Contemporary Introduction. London: Routledge.

Rosenberg, A. (2007). Philosophy of Social Science. Westview Press; 3 edition.

Rose, S. (1998). What is wrong with reductionist explanations of behaviour? Novartis Foundation Symposium, 213, 218-221.

Skurvydas, A. (2005). New methodology in biomedical science: Methodological errors in classical science. $\mathrm{Me}$ dicina, 41 (1), 7-16.

Skurvydas, A. (2008). Senasis ir naujasis mokslas: paradigmos, metodologijos, teorijos, desniai, principai, politika. Kaunas: LKKA.

Skurvydas, A. (2003). Sistemų ir evoliucinès paradigmos iššūkis sporto mokslui. Ugdymas. Kūno kultūra. Sportas, 3 (48), 58-63.

Skytner, L. (2006). General Systems Theory: Perspectives, Problems, Practice. 2 edition. World Scientific Publishing Company.

Strogatz, S. (2003). Sync: The Emerging Science of Spontaneous Order. New York: Hyperion.

Weinberg, G. M. (2001). An Introduction to General Systems Thinking. 1st edition .Dorset House Publishing Company, Incorporated.

\title{
NEW SCIENCE - COMPLEX DYNAMIC SYSTEMS - RESEARCH PARADIGM: FROM BIOLOGY TO LAW
}

\author{
Albertas Skurvydas ${ }^{1,2}$, Dovilè Valančiene $\dot{e}^{3}$ \\ Lithuanian Academy of Physical Education ${ }^{1}$, Kaunas, Klaipéda University ${ }^{2}$, Klaipéda, \\ Vilnius University ${ }^{3}$, Vilnius, Lithuania
}

\begin{abstract}
The main purpose of the article is to review the advantages and disadvantages of the new science paradigm - complex dynamic systems. In the present-day world changes in the science paradigm are in progress. Presently, the new science is rejecting the old science. One of the greatest errors made by the old science was determining strict limits between separate sciences. This delimitation resulted in a multitude of separate science "specialists" and, as a consequence, very few nowadays realize the true nature of science. Thus, there is a struggle between the old - deterministic thinking based on search for complete clearness and objectivity, on the one hand, and the new - the paradigm of complex dynamic systems, on the other hand. The new science paradigm does not regard the possibilities of cognition as the absolute ones coming to realize ever more fully that each act of cognition depends not only on the weaknesses of the subject alone but also on the complexity and dynamics of the object, i. e. on the impossibility to precisely cognize and understand it in principle. Who is the winner at present? There is a doubt that the old science, possessing greater experience and more "patrons", turns out to be the winner. This victory, however, is a frail and questionable one, since the leaders of various sciences are bravely revealing the faults of the old, deterministic and reductionistic science and pointing out the advantages of the new science.
\end{abstract}

Keywords: complex dynamic systems, chaos, science paradigm.

Gauta 2009 m. gegužès 24 d.

Received on May 24, 2009

Priimta $2009 \mathrm{~m}$. lapkričio $10 \mathrm{~d}$.

Accepted on November 10, 2009
Albertas Skurvydas

Lietuvos kūno kultūros akademija

(Lithuanian Academy of Physical Education)

Sporto g. 6, LT-44221 Kaunas

Lietuva (Lithuania)

Tel +37068614700

E-mail a.skurvydas@lkka.1t 